\title{
FAMILY SYSTEMS IN VADAR COMMUNITY ON MAHARASHTRA
}

\author{
Dr. Pisal Anita Sambhaji \\ Assistant Professor,Bharati Vidyapeeth University,Social Science centre, Pune. \\ DOI: 10.46609/IJSSER.2021.v06i04.012 URL: https://doi.org/10.46609/IJSSER.2021.v06i04.012
}

\begin{abstract}
Vadar community is one of the many Indian nomadic communities, known for their hard laborious work though they arefound all over India. They are mainly concentrated in Andhra Pradesh, Maharashtra and Karnataka. Vadar community is recognized as hard working people had been working with stones and mining work. These people are called Vadar in Maharashtra. Basic needs of every human being are fulfilled. Vadar community it is help directly or indirectly to full fill the basic needs and therefore, people of this community are scattered all over India. They have acquired traditions and customs' ofrespective status in the courses of times.
\end{abstract}

\section{Introduction}

Vadar community known as slogging work in the scorching sun. It is also recognized as hard working community. These people mainly work in stone mine, as traditional work. In Stone Age these people invented grinding stone. In this way vadar people invented manly stone apparatus which can be used the ancient work tradition of this community. Today their constructions are no more required by the society.

They built wells ponds, dams, channels, for storage and water supply. They also built residing places made of stone such as palaces and houses. In the modern times they excited their skills in making railways, roads and Bridges over the rivers. Their work man ship was also appreciated as they had carved famous idols of Gods and Goddess. Many history places also built by vadar community.

Vadar community people are different from the other castes in India. The dressing style, language, marriage system, festivals and other social events are also different than other communities. They have acquired more or less traditions and customs of other communities of different communities in respective States of India.

It would not be exaggeration if we say that People from Vadar community are first Engineers as 
they are considered to be the first people who made weapons from the stone. The Vadar community is known by different names in India such as Mati Vadar, Gadi Vadar, Kala Vadar, Patharvat Vadar, Jati Vadar, Jati, Bhoaj etc.

We would see Vadar man with image on our mind as toiling man, making roads, breaking stones along with his family members around, helping him one or the other way. Generally women of his family are there with him in his hard work. We would see her as a woman with 9 yard saree and choli (beltless blouse), germanium or brass bangle in her hand, without bindi on her forehead, many tattoos on her arms and face.

\section{Family Systems in Vadar Society}

Since long back we know that Vadar community migrate from one place to other in search of work to earn their living. Even today thiscan be seen to some extent. This society likes to be in joint family. But now days it has become impractical. So these people have been getting attracted to cities. This is due to availability of wages. This is the cause that the joint family system in Vadar community. Sometimes single parenting family also seen in this community. The divorce and other family disputes were very rare in this community.

The average family size is 6 persons of the respondent's in vadar community families. It is observed according to the study that the Vadar communities have all type of family it was found that out of 522, respondents were belongs to joint family, nuclear family and signal family.

More than two generations would live together. These include grandparents with children and grandchildren. In some families even daughters with their family members were found living together.

Table No. 3.1

Statement Showing Caste by Type of Family

\begin{tabular}{|c|c|c|c|c|}
\hline \multirow{2}{*}{$\begin{array}{c}\text { Sub } \\
\text { Castes of } \\
\text { Vadar } \\
\text { Communit } \\
\mathbf{y}\end{array}$} & \multicolumn{3}{|c|}{ Type of Family } & \multirow{2}{*}{ Total } \\
\hline & $\begin{array}{c}\text { Joint } \\
\text { Family }\end{array}$ & $\begin{array}{l}\text { Nuclear } \\
\text { Family }\end{array}$ & $\begin{array}{l}\text { Singl } \\
\text { e } \\
\text { Fami } \\
\text { ly }\end{array}$ & \\
\hline & 176 & 93 & 2 & 271 \\
\hline
\end{tabular}


International Journal of Social Science and Economic Research

ISSN: 2455-8834

Volume:06, Issue:04 "April 2021"

\begin{tabular}{|l|c|c|c|c|}
\hline \multirow{2}{*}{ Gadi Vadar } & $33.7 \%$ & $\begin{array}{c}18 \\
\%\end{array}$ & $.4 \%$ & $51.9 \%$ \\
\hline \multirow{3}{*}{ Mati Vadar } & 33 & 60 & 8 & 176 \\
& & & 3 & \\
\cline { 2 - 5 } & $6.3 \%$ & $11.5 \%$ & $15.9 \%$ & $33.7 \%$ \\
\hline \multirow{3}{*}{ Pathrut Vadar } & 20 & 25 & 4 & 49 \\
\cline { 2 - 5 } & 3.8 & $4.8 \%$ & $.8 \%$ & $9.4 \%$ \\
\hline \multirow{3}{*}{ Jati Vadar } & 11 & 15 & 0 & 26 \\
\hline \multirow{3}{*}{ Total } & $2.1 \%$ & $2.9 \%$ & - & $5.0 \%$ \\
& $\mathbf{2 4 0}$ & $\mathbf{1 9 3}$ & $\mathbf{8}$ & $\mathbf{5 2 2}$ \\
\cline { 2 - 5 } & $\mathbf{4 5 . 9 \%}$ & $\mathbf{3 6 . 9 \%}$ & $\mathbf{1 7 \%}$ & $\mathbf{1 0 0 . 0}$ \\
\hline
\end{tabular}

The above table the researcher conducted in her research that out of 522 numbers of respondents, 45.9 percent of the respondents were belongs to joint family system. 36.9 percent of the respondents were belonged to nuclear family system. 17 percent respondents were belonged to signal family.

\section{Accommodations}

Previously, Vadar people used to live at the outskirts of the town or on the banks of river in the temporary huts. Once the work there is over they used to move to other place. So there hut used to be temporarybut beautiful house for them. It presently it has changed to some extent. $60 \%$ respondents have been found settled last 25 years. 17\% respondents have been settled last 50 years.

But still some families from this community have seen living on roads today. This picture is seen mainly in the cities wherever some building work is going on. Many times they take shelter at their relatives. It shows that even today some people from this community don't have proper houses. Some of them have permanent houses and some still live in temporary houses and of course they are of very low grade.

One of the basic necessities of human life is a house to live in. Owen ship of such necessities gives a psychological satisfaction. It also reflects the economic status and living standard of the people. Vadar communities living in community have, by and large, had their own houses and very few live in rented accommodation. The housing pattern in community is generally a 
reflection of social status. Therefore, people belonging to a particular community, generally, reside in a particular area of the community.

Table No. 3.2

Statement showing Accommodations Statues of theRespondents

\begin{tabular}{|c|l|c|c|}
\hline Sr.N & $\begin{array}{r}\text { Status } \begin{array}{r}\text { of } \\
\text { Accommodation }\end{array} \\
\text { o }\end{array}$ & $\begin{array}{c}\text { No } \\
\text { respondents }\end{array}$ & $\begin{array}{c}\text { Percenta } \\
\text { ge }\end{array}$ \\
\hline 1. & Rented House & 117 & $22.4 \%$ \\
\hline 2. & Own Houses & 372 & $71.3 \%$ \\
\hline 3. & Staying with Relative & 33 & $6.3 \%$ \\
\hline & $\begin{array}{c}\text { Tot } \\
\text { al }\end{array}$ & $\mathbf{5 2 2}$ & $\mathbf{1 0 0 \%}$ \\
\hline
\end{tabular}

It is seen that 22 percent of the respondents were stay in rented house, 71 percent of the respondents were stay in their own home. 6 percent of the respondents were staying in Relative houses. It shows thatmost of the members of the Vadar community are quite settled in their own houses.

\section{Language}

It is said that language of Vadar community has become a grave problem today. It has immense impact of modernization and media. New generation of Vadar community don't know much above their language and also don't feel need of their language. Also they don't like to learn that language. In schools, at home everywhere for all the formal and informal communications, Marathi is used. Customs and Traditions of Vadar:

Vadar community gives importance to their customs and traditions. Fair of their family God, His worship celebration every yeartraditional way. These customs and traditions are taught to new generations it is inculcated in new generations.

\section{Caste Panchayat [Jat Panchayat]:}

In the old days there used to be caste panchayat. Seniors in the society used to make all the decisions about the society. Every family was bound to observe the rules and regulations decided by caste panchyat. If someone tries to do the things which are not acceptable by caste panchayat was punished. Caste panchayat would make decision about that person. All the good and bad 
matters were solved by caste panchayat. Right from wedding up to the funeral rituals everything used to decide by the caste panchayat. But today there are few has been castepanchayats seen. People moved to many different places in search of work or for education etc. So people of Vadar society are scattered now. Wherever one found his job or work, he settled their itself. At present everyone seeks help from police and court for the justice. This is also major change in Vadar society.

\section{Food and Habits}

Food, clothes and shelter are the fundamental needs of a human being. It is very necessary that the man should have his food according to the work he does. Vadar people are mostly non vegetarian. These people used to hunt. They would hunt rabbits, dears, pigs and various birds for their food. Sometimes they would catch fish and crabs from nearby streams or rivers. So, nonvegetarian food is their favorite food But we can see changes in the food habits just like other changes.

Vadar people move from one place to another place in search of work. A person in Vadar society has capacity to toil, can break huge stones and they work hard in the field drink liquor to relax themselves.

\section{Fairs and Festival}

Vadar culture is prominently different. They arrange fairs of their Gods like Laxmidevi, Yallamma, Hanuman, and Siddhanath twice in a year. They spend lot of money for arrangements of these fairs. They trust God a lot. They do not compromise on God's festivals etc. festivalsand functions are celebrated in this way. They celebrate Diwali, Holi, etc.

It is seen that all the customs are led by further generations. Even fairs are conducted as the custom from previous generations. Next generations follows these customs. They try to perform all these customs rigidly if at all there are some financial problems. Today too Vadar community gives great importance to the customs in their society.

Table No. 3.3

\section{Festival Celebrations in Respondents}

\begin{tabular}{|l|c|c|}
\hline \multicolumn{1}{|c|}{$\begin{array}{c}\text { Festiv } \\
\text { al }\end{array}$} & $\begin{array}{c}\text { Frequen } \\
\text { cy }\end{array}$ & $\begin{array}{c}\text { Perce } \\
\text { nt }\end{array}$ \\
\hline Laximidevi Yatra & 145 & $28 \%$ \\
\hline Yallamadevi Yatra & 60 & $12 \%$ \\
\hline
\end{tabular}


International Journal of Social Science and Economic Research

ISSN: 2455-8834

Volume:06, Issue:04 "April 2021"

\begin{tabular}{|l|c|c|}
\hline Hanuman Jati & 217 & $41 \%$ \\
\hline Sidhanath Yatra & 70 & $13 \%$ \\
\hline Masobha Tatra & 30 & $6 \%$ \\
\hline Total & $\mathbf{5 2 2}$ & $\mathbf{1 0 0}$ \\
\hline
\end{tabular}

It is seen from the table that, 41 percent of the respondents were celebrating in Hanuman Jati. 28 percent of the respondents were Celebrating in Laximidevi Yatra. 12 percent of the respondents were Celebrating in Laximidevi Yatra. 13 percent of the respondents were celebrating Sidhanath Yatra.6\% of the respondents were celebratingMasoba Yatra.

It is concluded that, most of them respondents were celebrating inHanuman Jati and Laximidev in yatra in Pune and district.

\section{Conclusion}

- The Vadar community families were always in started migrate from one place to another but it was settle the community after independence rapidly. It is one of the important observations seen by researcher.

- Most of the members of the Vadar community are quite settled in their own houses. Language is the prime identity of Vadar community. This can be sensed that this identity has been gradually disappearing.

- The new generation is very much conscious about it prestige. They avoid speaking their own language in this way they disregard their own identity.

- It is found that the non-vegetarian food is less consumed as they have realized that vegetarian food is also equally important. To the surprise, some families are seen who are totally vegetarian now.

\section{References}

1). MYTH AND IDENTITY:THE NARRATIVE CONSTRUCTION OF SELF IN THE ORALTRADITION OF VADÄR COMMUNITIESCopyright $\odot$ 2001, Indian Folklore Research Journal,Volume One, Number One, May 2001Guy Poitevin Centre for Co-op. Research in Social Science, Rair Kar Bungalow,884, Deccan Gymkhana, Pune - 411 004, Maharashtra, India

2). ACK-070: Jasma of Odes .Posted by PBC Sunday, February 15, 2009 
International Journal of Social Science and Economic Research

ISSN: 2455-8834

Volume:06, Issue:04 "April 2021"

[http://ncbc.nic.in/backward-classes/maharashtra.html

3). Centre for Co-op. Research in Social Science, Rair Kar Bungalow,884, Deccan Gymkhana, Pune - 411 004, Maharashtra, India

4). Caste/Tribal Diversity in Andhra Pradesh

5). Chief Ministers of Andhra Pradesh,Caste system isn't racism and our best sociologists and anthropologists are clear on . this,http://www.bharatvani.org/indology/Ilaiah.html 